\title{
The Application of Experimental Methods to Improve Science Learning Outcomes for Fourth Grade Students at Elementary School
}

\author{
Aman Sugianto \\ SD Negeri Pabuaran 02 \\ danustudio2017@gmail.com
}

\section{Article History}

received 3/12/2020

revised 17/12/2020

accepted 31/12/2020

\begin{abstract}
The purpose of this research was to improve the learning outcomes of fourth grade students at SD Negeri Pabuaran 02 in science subjects through the application of experimental methods. The research that was conducted was Classroom Action Research (CAR) which was carried out in two cycles of action, each cycle consisting of two meetings. The stages for each cycle are planning, implementation, observation and reflection. Data was collected using observation techniques, documentation studies and tests. The results of the first cycle of research showed that students who completed the post-test were $63.6 \%$. In the implementation of the second cycle of students who completed after carrying out the post test was $95.5 \%$. These results indicate that the application of the experimental method can improve student learning outcomes in science subjects Class IV at SD Negeri Pabuaran 02, especially on the material properties of light.
\end{abstract}

Keywords: learning outcomes, experimen method, science

\begin{abstract}
Abstrak
Tujuan penelitian ini adalah untuk meningkatkan hasil belajar peserta didik kelas IV SD Negeri Pabuaran 02 pada mata pelajaran IPA melalui penerapan metode eksperimen. Penelitian yang dilakukan adalah jenis Penelitian Tindakan Kelas (PTK) yang dilaksanakan sebanyak dua siklus tindakan, setiap siklus terdiri dari dua pertemuan. Tahapan untuk setiap siklusnya yaitu perencanaan, pelaksanaan, pengamatan dan refleksi. Pengumpulan data dilakukan menggunakan teknik observasi, studi dokumentasi dan tes. Hasil penelitian siklus I menunjukkan peserta didik yang tuntas setelah melaksanakan post tes adalah sebesar $63,6 \%$. Pada pelaksanaan siklus II siswa yang tuntas setelah melaksanakan post tes adalah sebesar $95,5 \%$. Hasil ini menunjukan bahwa penerapan metode eksperimen dapat meningkatkan hasil belajar peserta didik pada mata pelajaran IPA Kelas IV di SD Negeri Pabuaran 02, khususnya pada materi sifatp-sifat cahaya.
\end{abstract}

Kata kunci: hasil belajar, metode eksperimen, IPA

Social, Humanities, and Education Studies (SHEs): Conference Series p-ISSN 2620-9284 https://jurnal.uns.ac.id/shes 


\section{PENDAHULUAN}

Pendidikan merupakan kunci utama bagi kemajuan suatu bangsa. Kemajuan suatu bangsa diawali dengan peningkatan kualitas sumber daya manusia melalui peningkatan kualitas pendidikan. Hal ini menegaskan bahwa pendidikan akan mempengaruhi kehidupan berbangsa dan bernegara. Jika kualitas pendidikan Indonesia meningkat maka akan meningkat pula kualitas bangsa Indonesia. Kualitas pendidikan akan terwujud jika pembelajaran dapat berlangsung secara efektif artinya proses pembelajaran dapat berjalan terarah dan sesuai dengan tujuan pembelajaran yang telah ditetapkan dalam kurikulum. Proses pembelajaran yang efektif hendaknya dilakukan setiap jenjang pendidikan khususnya pendidikan di sekolah dasar. Dalam keseluruhan proses pendidikan di sekolah, kegiatan belajar mengajar (pembelajaran) merupakan kegiatan yang paling pokok. Ini berarti bahwa berhasil tidaknya pencapaian tujuan pendidikan banyak bergantung kepada bagaimana proses belajar yang dialami oleh siswa sebagai anak didik.

Guru merupakan faktor yang paling dominan yang menentukan kualitas pembelajaran. Kualitas pembelajaran yang baik tentu akan menghasilkan hasil belajar yang baik pula. Dalam sistem pembelajaran saat ini guru dituntut untuk bisa membawa peserta didik ke dalam proses pembelajaran yang menarik dan menyenangkan. Peserta didik yang merasa nyaman dan senang, maka akan lebih mudah untuk menerima dan memahami materi yang disampaikan. Guru harus bisa menentukan model maupun metode pembelajaran yang tepat yang susuai dengan karakteristik materi yang disampaikan, karena tidak semua metode pembelajaran dapat digunakan untuk semua materi pembelajaran. Pemilihan metode pembelajaran akan mendukung hasil pembelajaran yang akan dicapai peserta didik.

Salah satu muatan pelajaran yang menuntut penggunaan metode pembelajaran yang sesuai adalah muatan pelajaran Ilmu Pengetahuan Alam (IPA). Ahmad dalam Nurhaliza (2018) menyatakan bahwa IPA merupakan salah satu mata pelajaran utama dalam kurikulum pendidikan di Indonesia, mulai jenjang sekolah dasar sampai dengan sekolah menengah. Ilmu Pengetahuan Alam (IPA) atau yang juga sering disebut dengan SAINS adalah ilmu yang berhubungan dengan gejala-gejala alam dan kebendaan yang sistematis, tersusun secara teratur, berlaku secara umum, berupa kumpulan hasil observasi dan eksperimen (Nana Djumhana, 2009). Dengan demikian sains tidak hanya sebagai kumpulan tentang benda atau makhluk hidup, tetapi tentang cara kerja, cara berfikir, dan cara memecahkan masalah. Oleh karena itu dalam pembelajaran mata pelajaran IPA, tidak semua materi bisa dilihat saja, akan tetapi butuh dipraktikkan dan diujicobakan secara lansung untuk mengetahui dan memahami konsep dengan benar. Pembelajaran IPA dengan memberikan pengalaman langsung dapat menumbuhkan cognitive thingking skill (keterampilan berpikir kognitif), psychomotor skills (keterampilan psikomotorik) dan social skills (keterampilan sosial) (Prabowo, 2015).

Penerapan metode pembelajaran harus sesuai dengan materi yang disampaikan, jika tidak sesuai maka tujuan pembelajaran yang diiginkan akan sulit untuk tercapai. Hasil belajar IPA juga akan rendah jika peserta didik tidak memahami konsep maupun penerapan materi pelajaran yang disampaikan. Rendahnya pemahaman peserta didik terhadap materi IPA masih banyak di jumpai di sekolahsekolah, seperti halnya di SD Negeri Pabuaran 02 Kecamatan Salem. Hasil belajar IPA peserta didik kelas IV pada materi sifat-sifat cahaya masih rendah, hal ini dapat dilihat dari hasil penilaian ulangan harian dimana dari 22 peserta didik hanya 4 peserta didik $(18,2 \%)$ yang sudah dinyatakan tuntas dengan Kriteria Ketuntasan Minimum (KKM) IPA sebesar 65 . Ketuntasan belajar klasikal belum tercapai, yaitu sebesar $85 \%$ peserta didik memperoleh nilai di atas KKM.

Hasil belajar merupakan perubahan prilaku individu yang meliputi ranah kognitif, afektif, dan psikomotorik (Rusmono, 2012). Menurut fungsinya hasil belajar 
bukan saja untuk mengetahui sejauh mana siswa telah menyelesaikan suatu aktifitas tetapi lebih penting adalah sebagai alat untuk memotivasi siswa agar lebih giat dalam belajar baik secara individu maupun kelompok. Sedangkan menurut Rusman (2013) hasil belajar adalah kemampuan yang dimiliki siswa setelah ia menerima pengalaman belajarnya. Sejumlah pengalaman yang diperoleh siswa tersebut mencakup ranah kognitif, afektif dan psikomotorik. Dari pernyataan-pernyataan di atas dapat disimpulkan bahwa pengertian hasil belajar adalah sebuah parameter tingkat keberhasilan proses belajar yang ditunjukkan oleh besaran angka yang didapatkan dalam kegiatan ujian, dan juga perubahan tingkah laku yang terjadi dari seorang siswa.

Pembelajaran IPA di SD/MI, dapat dilakukan dengan penyelidikan sederhana dan bukan hafalan terhadap kumpulan konsep IPA (Faizi, 2013). Dalam penelitian ini pada pembelajaran IPA dengan menggunakan metode eksperimen yang merupakan salah satu metode yang relevan dengan teori belajar konstuktivisme. Teori belajar konstruktivistik memahami belajar sebagai proses pembentukan (kontruksi) pengetahuan oleh peserta didik itu sendiri. Pengetahuan ada di dalam diri seseorang yang sedang mengetahui. Dengan kata lain, karena pembentukan pengetahuan adalah peserta didik itu sendiri, peserta didik harus aktif selama kegiatan pembelajaran, aktif berpikir, menyusun kosep, dan memberi makna tentang hal-hal yang sedang dipelajari, tetapi yang paling menentukan terwujudnya gejala belajar adalah niat belajar peserta didik itu sendiri. Metode eksperimen adalah cara penyajian pelajaran, dimana siswa melakukan percobaan dengan mengalami dan membuktikan sendiri sesuatu yang dipelajari (Djamarah, 2010).

Sagala dalam Puryadi (2017) mendefinisikan bahwa metode eksperimen adalah cara penyajian pelajaran, dimana siswa diberi kesempatan untuk melakukan sendiri suatu proses mengamati suatu objek, menganalisa, membuktikan dan menarik kesimpulan sendiri mengenai objek yang dieksperimenkan tersebut. Dengan demikian, siswa dituntut melakukan sendiri, mencari sendiri, atau mencoba suatu hukum atau dalil, dan mencari kesimpulan dari proses yang dialami.

Selanjutnya Hasan dalam Cahaya (2015) menyatakan bahwa eksperimen adalah percobaan yang bersistem dan berencana (untuk membuktikan kebenaran suatu teori dan sebagainya). Dari berbagai pendapat yang disampaikan oleh para ahli di atas, dapat disimpulkan dalam proses pembelajaran dengan metode ini siswa diberi kesempatan untuk mengalami atau melakukan sendiri, mengikuti suatu proses, mengamati suatu objek, menganalisis, membuktikan, dan menarik kesimpulan sendiri mengenai suatu objek, keadaan, atau proses sesuatu.

Berdasarkan uraian di atas dalam upaya meningkatkan hasil belajar IPA materi sifat-sifat cahaya pada peserta didik kelas IV SD Negeri Pabauran 02, maka peneliti mencoba menerapkan metode eksperimen. Banyak penelitian yang telah dilakukan dengan menerapkan metode eksperimen untuk meningkatkan hasil belajar salah satunya ialah penelitian yang dilakukan oleh Evi Asmawira (2013) menunjukkan bahwa hasil belajar siswa meningkat dengan memanfaatkan metode eksperimen.

\section{METODE}

Penelitian ini merupakan Penelitian Tindakan Kelas (Classroom Action Research) dengan menerapkan metode eksperimen. Menurut Wardani (2010) bahwa langkah-langkah Penelitian Tindakan Kelas (PTK) terdiri dari empat tahap, yaitu merencanakan (planning), melakukan tindakan (acting), mengamati (observing), dan melakukan refleksi (reflecting). Analisis penelitian ini adalah analisis deskriptif kuantitafif kualitatif dimana dalam penelitian ini selain penyajian hasil berupa data maupun angka peneliti juga menentukan bagaimana cara pengolahan hasil penelitian yakni dengan membuat analisisnya penerapan metode eksperimen dengan membandingkan hasil setiap siklus pelaksanaan. Penelitian ini dilaksanakan pada peserta didik kelas IV SD Negeri 2 Pabuaran 02 Tahun Pelajaran 2018/2019 dalam 
dua siklus pembelajaran dengan dua pertemuan disetiap siklusnya. Siklus I dilaksanakan pada tanggal 7 dan 14 Maret 2019. Siklus II dilaksanakan pada tanggal 21 dan 28 Maret 2019. Teknik pengumpulan data yang dilakukan dengan observasi dan tes, aik pre test maupun post test. Observasi meliputi observasi penerapan metode eksperimen dalam pembelajaran, aktivitas dan keterampila peserta didik serta aktivitas guru. Untuk mengetahui hasil belajar dengan menggunakan tes tulis dengan soal berbentuk pilihan ganda.

\section{HASIL DAN PEMBAHASAN}

Pada pelaksanaan tindakan siklus I pembelajaran dilaksanakan dalam dua pertemuan, post test dilaksanakan pada akhir pertemuan kedua untuk mengetahui peningkatan hasil belajar peserta didik setelah dilaksanakan pembelajaran IPA dengan pada materi sifat-sifat cahaya. Pada pembelajaran siklus I membahas materi tentang konsep cahaya dan sifat-sifatnya yang akan dianalisis peserta didik melalui beberapa buah percobaan untuk menganalisis sifat cahaya yaitu percobaan sifat cahaya dapat menembus benda bening dan cahaya dapat dipantulkan yang dikolaborasikan dengan metode diskusi kelompok. Penerapan metode eksperimen ini dilaksanakan dengan mengacu pada prosedur pelaksanaan metode eksperimen, yaitu menjelaskan tujuan eksperimen mereka harus memahami masalah yang akan dibuktikan melalui eksperimen, memberi penjelasan kepada siswa tentang alat-alat serta bahan-bahan yang akan digunakan dalam eksperimen, selama eksperimen berlangsung guru harus mengawasi pekerjaan siswa dan mengumpulkan hasil penelitian siswa, mendiskusikan di kelas, dan mengevaluasi dengan tes atau tanya jawab. Hasil tes peserta didik pada siklus I dapat dilihat pada tabel berikut.

Tabel 1. Hasil Belajar IPA Peserta Didik Siklus I

\begin{tabular}{ccccc}
\hline \multirow{2}{*}{ Pembelajaran } & \multicolumn{2}{c}{ Peserta Didik Tuntas } & \multicolumn{2}{c}{$\begin{array}{c}\text { Peserta Didik Belum } \\
\text { Tuntas }\end{array}$} \\
\cline { 2 - 5 } & Jml & $\%$ & Jml & $\%$ \\
\hline Siklus I & 14 & 63,6 & 8 & 36,4 \\
\hline
\end{tabular}

Berdasarkan tabel di atas dapat kita ketahui bahwa pada pembelajaran IPA Siklus I dengan menerapkan metode eksperimen peserta didik yang tuntas mencapai nilai KKM adalah sebanyak 14 peserta didik dengan persentase ketuntasan $63,6 \%$, sedangkan peserta didik yang belum tuntas adalah sebanyak 8 peserta didik atau $36,4 \%$. Meskipun terjadi peningkatan hasil belajar dari pembelajaran awal (pra siklus) namun hasil pembelajaran Siklus I ini belum mencapai ketuntasan klasikal yang diharapkan yaitu 85\% dari jumlah peserta didik telah mencapai nilai KKM.

Berdasarkan refleksi hasil pembelajaran pada pembelajaran siklus I maka tindakan akan dilanjutkan dengan siklus II. Pada pembelajaran siklus II membahas kembali materi tentang sifat-sifat cahaya dengan melakukan kembali percobaan untuk menganalisis sifat cahaya dapat dibiaskan dan cahaya dapat merambat lurus dengan pembagian kelompok lebih kecil lagi dari pembelajaran siklus I. Penerapan metode eksperimen ini dilaksanakan dengan mengacu pada prosedur pelaksanaan metode eksperimen seperti pada pelaksanaan siklus I. Adapun hasil post test evaluasi peserta didik pada pembelajaran siklus II mata pelajaran IPA dapat dilihat pada tabel berikut. 
Tabel 2. Hasil Belajar IPA Peserta Didik Siklus II

\begin{tabular}{ccccc}
\hline \multirow{2}{*}{ Pembelajaran } & \multicolumn{2}{c}{ Peserta Didik Tuntas } & $\begin{array}{c}\text { Peserta Didik Belum } \\
\text { Tuntas }\end{array}$ \\
\cline { 2 - 5 } & Jml & $\%$ & Jml & $\%$ \\
\hline Siklus II & 21 & 95,5 & 1 & 4,5 \\
\hline
\end{tabular}

Berdasarkan tabel di atas dapat kita ketahui bahwa pada pembelajaran IPA materi sifat-sifat cahaya siklus II dengan menerapkan metode eksperimen peserta didik yang tuntas mencapai nilai KKM adalah sebanyak 21 peserta didik dengan persentase ketuntasan mencapai $95,5 \%$, sedangkan peserta didik yang belum tuntas hanya 1 peserta didik atau 4,5\%. Dari hasil pembelajaran siklus II persentase ketuntasan peserta didik telah mencapai $95,5 \%$ artinya telah mencapai ketuntasan klasikal yang diharapkan yaitu $85 \%$, maka pembelajaran dihentikan pada siklus II.

Berdasarkan hasil penelitian dari dua siklus pembelajaran di atas dapat kita ketahui adanya peningkatan persentase ketuntasan belajar siswa pada mata pelajaran IPA dengan menerapkan metode eksperimen dari siklus I ke siklus II. Data rekapitulasi ketuntasan belajar peserta didik dapat dilihat pada tabel di bawah ini.

Tabel 3. Rekapitulasi Ketuntasan Belajar Siklus I dan Siklus II

\begin{tabular}{lcccccc}
\hline Pembelajaran & \multirow{2}{*}{$\begin{array}{c}\text { Jumlah } \\
\text { Siswa }\end{array}$} & \multicolumn{2}{c}{ Siswa Tuntas } & \multicolumn{2}{c}{$\begin{array}{c}\text { Siswa belum } \\
\text { Tuntas }\end{array}$} & \multirow{2}{*}{$\begin{array}{c}\text { Peningkatan } \\
\%\end{array}$} \\
\cline { 3 - 6 } & & Jml & $\%$ & Jml & $\%$ & Ketuntasan \\
\hline Siklus I & 22 & 17 & 74,0 & 6 & 26 & 31,9 \\
Siklus II & 22 & 22 & 95,7 & 1 & 4,3 & 3 \\
\hline
\end{tabular}

Berdasarkan tabel di atas dapat kita ketahui bahwa pada pembelajaran siklus I dari 22 siswa yang mengikuti pembelajaran jumlah siswa yang tuntas adalah sebanyak 14 siswa dengan persentase ketuntasan 63,6\%. Peserta didik yang belum tuntas adalah 8 peserta didik atau sebesar $36.4 \%$ Pada pembelajaran siklus II, peserta didik yang tuntas adalah sebanyak 21 siswa dengan persentase ketuntasan sebesar $95,5 \%$. Peserta didik yang belum tuntas hanya 1 peserta didik atau 4,5\%. Terjadi peningkatan persentase ketuntasan beajar peserta didik dari siklus I ke siklus II sebesar 31,9\%.

Dari dua siklus pelaksanaan pembelajaran yang dilaksanakan dalam 4 kali pertemuan dapat diketahui bahwa penerapan metode eksperimen dapat meningkatkan hasil belajar peserta didik pada mata pelajaran IPA di Kelas IV SD Negeri Pabuaran 02 Kecamatan Salem. Dengan demikian dapat disimpulkan bahwa metode eksperimen dapat meningkatkan hasil belajar siswa. Hasil penelitian ini sesuai dengan teori-teori yang telah dikaji sebelumnya berdasarkan beberapa pendapat ahli bahwa metode eksperimen sangat tepat diterapkan dalam pembelajaran IPA di sekolah dasar karena siswa menjadi teribat aktif dalam pembelajaran.

Menurut Bruner, J. (dalam Hanafiah, 2012) terdapat empat alasan menggunakan metode eksperimen dalam menemukan fakta pada proses belajar siswa yaitu: dapat mengembangkan kemampuan intelektual siswa, mendapatkan motivasi intrinsik, menghayati bagaimana ilmu itu diperoleh, dan memperoleh daya ingat yang lebih lama retensinya. Sumantri dan Permana (dalam Puryadi, 2017) menyatakan bahwa kegiatan eksperimen yang dilakukan peserta didik usia SD merupakan kesempatan mereka melakukan suatu eksplorasi. Siswa akan memperoleh pengalaman meneliti yang mendorong mereka mengkontruksi pengetahuan mereka sendiri, berpikir ilmiah dan rasional sehingga hasil belajar menjadi kepemilikan peserta didik yang bertalian lama. Pada ranah kognitif metode eksperimen tidak hanya menekankan pada ingatan saja, tetapi juga dapat meningkatkan pemahaman dan penghayatan siswa pada materi pembelajaran. Siswa secara langsung terlibat dalam 
proses pembelajaran melalui percobaan, sehingga mereka mengkontruksi pengetahuan mereka sendiri. Dengan mengonstruksi, smembuktikan dan mengalaminya sendiri, maka siswa akan lebih paham dan memahami sebuah konsep dalam hal ini yaitu sifat-sifat cahaya. Melalui penggunaan metode eksperimen siswa dapat mengembangkan kemampuan intelektual mereka dengan mengaplikasikannya dalam kehidupan sehari-hari sehingga pembelajaran menjadi lebih berguna. Dengan demikian metode eksperimen dapat meningkatkan hasil belajar siswa menjadi lebih baik.

\section{SIMPULAN}

Penerapan metode eksperimen pada pembelajaran dapat meningkatkan hasil belajar peserta didik Kelas IV SD Negeri Pabuaran 02 pada mata pelajaran IPA materi sifat-sifat cahaya. Peningkatan yang terjadi karena adanya kesan pembelajaran yang mendalam dari peserta didik tehadap materi yang diajarkan melalui setiap percobaan yang dilakukan peserta didik. Dengan melakukan sendiri berbagai percobaan tentang sifat-sifat cahaya maka konsep sifat cahya akan lebih tertanam pada ingatan mereka, karena mereka menemukan dan membuktikan sendiri pengetahuan mereka pada saat melakukan percobaan. Berdasarkan penelitian yang telah dilaksanakan maka metode eksperimen merupakan salah satu metode pembelajaran yang harus dikuasai penerapannya oleh guru, dan merupakan salah satu metode yang cocok digunakan dalam pembelajaran IPA.

Dari hasil penelitian di atas peneliti mengajukan saran sebagai berikut: (1) guru harus dapat memilih dan menentukan metode maupun model yang tepat yang sesuai dengan karakteristik materi pelajaran (2) Bagi peneliti yang akan meneliti dengan menerapkan metode eksperimen, penelitian ini dapat dijadikan sebagai acuan atau referensi untuk membantu dalam melakukan penelitian. Selain itu diharapkan peneliti lain dapat mengkaji lebih lanjut mengenai penerapan metode eksperimen dalam pembelajaran.

\section{DAFTAR PUSTAKA}

Asmawira, E.. (2013). Penerapan Metode Eksperimen Terhadap Prestasi Belajar Siswa Pada Materi Gaya Di Kelas IV MIN Merduati Banda Aceh. Skripsi. IAIN Ar-Raniry, Banda Aceh.

Ningsih, C.S. (2015). Penerapan Metode Eksperimen Untuk Meningkatkan Keterampilan Proses Pada Pembelajaran IPA Siswa Kelas VI SDN Puro Pakualaman. Skripsi. UNY.

Djamarah, S.B.. (2010). Strategi Belajar Mengajar. Jakarta: Rineka Cipta.

Djumhana, N.. (2009). Pembelajaran IImu Pengetahuan Alam. Jakarta: Dirjen Pendidikan Islam

Faizi, M.. (2013). Ragam Metode Mengajar Eksakta Pada Murid (Cet.1), Jogjakarta: DIVA Press.

Nurhaliza, I. \& Jannah, Misbahul. (2018). Penerapan Metode Eksperimen Untuk Meningkatkan Hasil Belajar IPA Siswa Kelas V MIN 4 Aceh Besar. Jurnal Geuthèë: Penelitian Multidisiplin, 1(2), pp. 164 - 175.

Hanafiah, N.. (2012). Konsep Strategi Pembelajaran. Bandung: Refika Aditama

Puryadi \& Sahono, Bambang. (2017). Penerapan Metode Eksperimen Untuk Meningkatkan Sikap IImiah dan Prestasi Belajar Siswa. DIADIK : Jurnal IImiah Teknologi Pendidikan, 7(2). 2017.

Rusman. (2013). Belajar dan Pembelajaran Berbasis Komputer. Bandung: Alfabet.

Rusmono. (2012). Strategi Pembelajaran dengan Problem Based Learning. Bogor: Ghalia Indonesia.

Wardhani, I.G.A.K. (2010). Penelitian Tindakan Kelas (Cetakan Kesepuluh). Jakarta: Universitas Terbuka. 